\title{
PENGARUH SOSIOLOGI DALAM FIQH KEPEMIMPINAN WANITA
}

\author{
Fithriyatus Sholihah \\ UIN Walisongo Semarang \\ Email: fitrisholihah92@gmail.com
}

\begin{abstract}
Abstrak
Sejarah mencatat bagaimana wanita-wanita diperlakukan pada zaman dahulu. Jangankan untuk menjadi seorang pemimpin, hak untuk hidup saja mereka tidak punya. Sebagaimana yang terjadi di masyarakat Jahiliyyah dulu, bayi perempuan dikubur hidup-hidup begitu mereka dilahirkan. Fenomena itu terjadi sebenarnya dikarenakan oleh faktor sosio-kultural maupun sosio-historis yang ada di masyarakat, di mana wanita selalu dianggap lemah dan pria selalu diagung-agungkan dengan segala kehebatannya. Oleh karena itu, adanya larangan tentang kepemimpinan wanita sebenarnya bukan lahir dari faktor keagamaan, melainkan dari kondisi social budaya maupun social historis dalam masyarakat itu sendiri. Apabila dalam masyarakat zaman dahulu wanita tidak dapat menjadi pemimpin karena dianggap lemah dari berbagai segi, intelektual dan kemampuan misalnya. Hal itu tidak dapat diterapkan lagi dalam kondisi social masyarakat saat ini, di mana kaum wanita sudah banyak yang mengenyam pendidikan setinggi-tingginya, dalam suatu kasus bahkan kecerdasan mereka telah melebihi kaum pria, hal ini tentunya membuka kesempatan yang luas bagi kaum wanita untuk menjadi pemimpin.
\end{abstract}

Kata Kunci: Pengaruh Sosiologi, Fiqh, Kepemimpinan Wanita

Abstract: History records how women were treated in ancient times. Never mind to be a leader, they don't have the right to live. As happened in the old Jahiliyyah society, baby girls were buried alive as soon as they were born. This phenomenon actually occurs due to socio-cultural and socio-historical factors that exist in society, where women are always considered weak and men are always exalted with all their greatness. Therefore, the prohibition on women's leadership is not actually born from religious factors, but from the socio-cultural and social-historical conditions in the society it self. In ancient society, women could not be leaders because they were considered weak in various ways, for example in intellectually and capability. This cannot be applied anymore in the current social conditions of society, where many women have received the highest education, in one case even their intelligence has exceeded that of men, this of course opens wide opportunities for women to become leaders.

Key words : Sociological Influences, Fiqh, Female Leadership

\section{Pendahuluan}

Sejarah mencatat bagaimana kedudukan wanita pada zaman dahulu, jangankan menjadi seorang pemimpin, mempunyai hak hidup saja tidak. Sebagaimana kebiasaan masyarakat Arab jahiliyyah yang mengubur hidup-hidup anak perempuannya, bahkan wanita dapat diwariskan dan diperjual belikan.

Setelah Islam datang, secara bertahap Islam mengembalikan hak-hak wanita sebagai manusia merdeka. Seorang wanita boleh menjadi saksi dan berhak atas sejumlah warisan, meskipun keduanya hanya bernilai setengah dari kesaksian atau jumlah warisan yang berhak diterima oleh laki-laki.

Di Indonesia sendiri, sejak masa perjuangan merebut kemerdekaan, kaum wanita telah ikut berpartisipasi mengusir penjajah. Namun setelah kemerdekaan, peran wanita dalam mengisi kemerdekaan masih belum optimal. Wanita masih termarjinalkan dari beberapa aktivitas dan juga jabatan. Fenomena itu terjadi sebenarnya dikarenakan oleh faktor sosio kultural maupun sosio historis yang ada di masyarakat, di mana wanita selalu dianggap lemah dan pria selalu diagung-agungkan dengan segala kehebatannya.

Di era modern ini, wanita tidak lagi lemah, baik dalam segi fisik maupun akal. Pendidikan mereka tidak kalah dengan laki-laki, kemampuan mereka juga banyak diakui dunia luar. Dalam berbagai bidang, kemampuan dan kecerdasan wanita sebanding dengan pria, bahkan lebih tinggi. Sehingga, tidak menutup kemungkinan bagi wanita untuk melakukan aktivitas yang dulunya dilakukan oleh laki-laki, dan menduduki jabatan yang dulunya juga dikuasai oleh laki-laki.

\section{Metode Penelitian}

Penelitian ini merupakan penelitian normatif atau disebut juga dengan penelitian pustaka (kajian literatur)', yaitu penelitian yang sumber data primernya berasal dari buku. Oleh karena itu, pengumpulan bahan hukumya dilakukan dengan cara dokumentasi, dengan

\footnotetext{
${ }^{1}$ Soerjono Soekanto dan Sri Mamudji, Penelitian Hukum Normatif, (Jakarta: Rajawali Press, 2006), hlm. 13.
} 
cara: menentukan data (tulisan) yang akan dikumpulkan terkait dengan kedudukan wanita dari masa ke masa, mengidentifikasi judul-judul buku atau kitab yang relevan dan berkaitan dengan kepemimpinan wanita, membaca dan mempelajari buku-buku yang ada kaitannya dengan permasalahan dalam penelitian ini, membuat kesimpulan dari apa yang telah dibaca. Pendekatan yang digunakan adalah pendekatan konseptual, sedangkan teknik analisisnya adalah dengan cara mengedit, mengklasifikasi, menganalisis dan menyimpulkan. Sementara itu, pengecekan keabsahan data akan dilakukan dengan dengan pola triangulasi pada bahan data, teori dan peneliti.

\section{Kedudukan Wanita dalam Islam}

Wanita mempunyai kedudukan yang tinggi dalam Islam dan pengaruh yang besar dalam kehidupan manusia. Dia akan menjadi madrasah pertama dalam membangun masyarakat yang shalih, ketika dia berjalan sesuai dengan petunjuk al-Qur'an dan hadits. Dalam tatanan masyarakat Islam, wanita mempunyai kedudukan yang mulia, tidak mengurangi hak-hak mereka, juga tidak menjadikan nilai kemanusiannya rapuh. Sebagaimana yang tercantum dalam al-Qur'an surat at-Taubah ayat 7I:

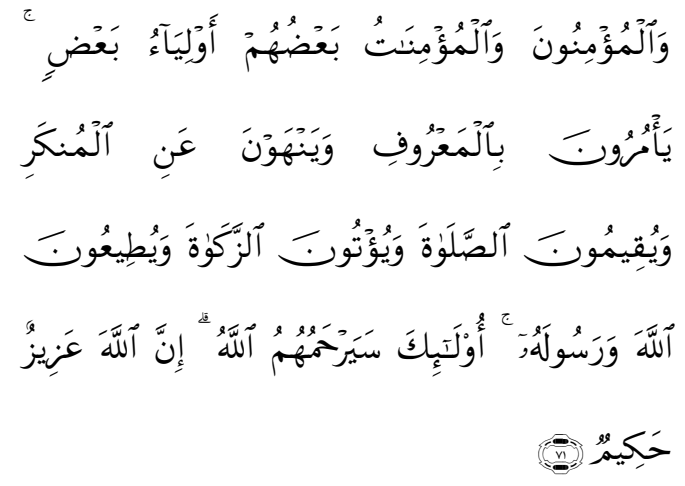

"dan orang-orang yang beriman, lelaki dan perempuan, sebahagian mereka (adalah) menjadi penolong bagi sebahagian yang lain. mereka menyuruh (mengerjakan) yang ma'ruf, mencegah dari yang munkar, mendirikan shalat, menunaikan zakat dan mereka taat pada Allah dan Rasul-Nya. mereka itu akan diberi rahmat oleh Allah; Sesungguhnya Allah Maha Perkasa lagi Maha Bijaksana. (Q.S. at-Taubah: 7I)

Islam memuliakan wanita dalam porsi istimewa dengan mengangkat derajat wanita setinggitingginya, setelah sebelumnya pada zaman Jahiliyyah wanita dapat diperjual belikan, menjadi komoditas, dan direndahkan derajatnya. Pandangan Islam terhadap wanita sangat berbeda dengan pandangan bangsabangsa lain zaman dahulu.

Pada tahun $586 \mathrm{M}$, bangsa Perancis pernah mengadakan kongres dengan tema "apakah wanita tergolong sebagai manusia yang mempunyai hak dan kewajiban, ataukah tidak tergolong sebagai manusia ?" dan hasil dari kongres itu adalah bahwa wanita merupakan manusia ciptaan Tuhan dengan tugas melayani laki-laki semata.

Sementara itu, UU Kerajaan Inggris sampai tahun 1805 M, masih membenarkan seorang suami menjual isterinya dengan nilai jual yang telah ditetapkan, yaitu seharga 6 pence. Pada tahun 196I M, di Italia masih terjadi seorang suami menjual isterinya kepada laki-laki dengan pembayaran kredit.

Bangsa Yunani tidak jauh berbeda dengan Perancis, Inggris dan Italia. Hal ini dapat dilihat dari pendapat Aristoteles yang menyatakan bahwa, tujuan dan sentral dari segenap makhluk ini bukanlah pada seluruh manusia, tetapi hanya pada laki-laki saja. Apabila seorang manusia melahirkan bayi perempuan berarti suatu hal yang jelek, dan seorang laki-laki pincang sama dengan separuh manusia. Sementara itu, Plato menyatakan rasa terima kasihnya kepada para Dewa, karena para Dewa telah memberikan enam macam berkah. Dua diantaranya yaitu dia dilahirkan ke dunia sebagai seorang yang merdeka, dan dia dilahirkan sebagai seorang laki-laki. ${ }^{2}$

Sedangkan Persia, sebelum Islam datang, mereka juga menghinakan dan meremehkan wanita serta perannya. Wanita hanya dianggap sebagai pelengkap saja tanpa mempunyai peran dan manfaat apa-apa, sehingga mereka sering dilecehkan dan didzalimi. Dalam agama Yahudi, wanita hanya sebagai pembantu pria saja. Seorang ayah diperbolehkan menjual anak perempuannya, dan hingga kini di Yahudi, wanita tidak mendapat bagian waris dari ayahnya kecuali apabila dalam keluarga tersebut tidak ada orang lain yang dapat menampung harta warisannya.

Sementara itu, di India dulu wanita tidak mendapat hak hidup ketika suaminya meninggal. Jadi, ketika suaminya meninggal dan dibakar, diapun harus ikut dibakar hidup-hidup menemani mayat suaminya. Tak jauh berbeda dengan Arab Jahiliyyah dulu, mereka mempunyai adat mengubur anak perempuannya hiduphidup ketika masih bayi, karena mempunyai anak perempuan dianggap sebagai aib bagi keluarga, sedangkan mempunyai anak laki-laki merupakan suatu kebanggaan tersendiri.

Oleh karena itu, tidak heran jika mayoritas intelektual dan sejarahwan, terutama di kalangan Islam, memandang posisi wanita pada masa pra Islam sebagai sebuah gambaran kehidupan yang sangat buram dan memprihatinkan. Wanita dianggap sebagai makhluk tidak berharga, keberadaannya sering menimbulkan

\footnotetext{
${ }^{2}$ Muhamad Thalib, Solusi Islam terhadap Dilema Wanita Karir, (Yogyakarta: Wihdah Press, 1999), h. 8.
} 
masalah, tidak memiliki independensi diri, hak-haknya ditindas dan dirampas, dapat diperjual belikan dan diwariskan, bahkan dikubur hidup-hidup, ditempatkan dalam posisi marginal dan pandangan-pandangan menyedihkan lainnya. ${ }^{3}$

Setelah Islam datang, secara bertahap hak-hak wanita sebagai manusia dikembalikan. Islam mempunyai falsafah yang khas mengenai hak-hak keluarga bagi pria dan wanita. Dalam pandangan Islam, kedudukan wanita di keluarga memberikan makna penjagaan syariat, dialah pendidik dan penanam utama syariat sejak dini kepada anggota keluarganya.

Islam tidak meyakini akan satu jenis hak, satu jenis kewajiban, dan satu jenis hukuman bagi pria dan wanita dalam segala hal. Islam memandang satu perangkat hak-hak dan kewajiban serta hukuman lebih sesuai bagi pria, dan satu perangkat lainnya lebih sesuai bagi wanita. Sebagai hasilnya, dalam beberapa hal Islam mengambil sikap yang sama terhadap wanita dan pria, dan dalam hal-hal lain Islam mengambil sikap yang berbeda-beda.

Hal-hal tersebut membuat para pembenci Islam memandang hukum Islam mengenai mahar, nafkah, perceraian, poligami, dan hukum-hukum lain seperti itu sebagai sesuatu yang merendahkan dan menghina wanita. Dengan cara demikian, mereka berusaha menciptakan kesan bahwa ketentuanketentuan itu sebagai bukti hanya kaum pria saja yang diutamakan, pria lebih mulia dari pada wanita, dan wanita diciptakan semata-mata untuk kemanfaatan dan kegunaan kaum pria. Mereka juga mengatakan bahwa Islam tidak mengakui wanita sebagai manusia yang sempurna, hal ini dapat dilihat dalam beberapa hal. Seperti, Islam tidak akan membenarkan poligami, tidak akan memberikan hak cerai kepada laki-laki, tidak akan menetapkan bahwa kesaksian dua wanita sama nilainya dengan kesaksian satu orang pria, dan lain sebagainya. Jika memang Islam mengakui wanita sebagai manusia yang sempurna, tentu Islam akan memberikan hak-hak yang sama antara pria dan wanita. ${ }^{4}$

Islam tidak pernah menganut pengutamaan dan diskriminasi yang menguntungkan pria dan merugikan wanita. Sebagai buktinya, dalam al-Qur'an, tidak terdapat satu ayat pun yang menyatakan bahwa wanita diciptakan dari suatu bahan yang lebih rendah dari pria, dan dalam Islam juga tidak ada satu pandanganpun yang meremehkan wanita berkenaan dengan watak dan struktur bawaannya. Pria dan wanita dipandang sebagai makhluk yang mulia, dan tidak

\footnotetext{
${ }^{3}$ Hartati, Ibu Teladan di Era Global: dalam Perspetif Islam, (Jakarta: Pusat Studi Wanita UIN Syarif Hidayatullah, 2006), h. 18 .

4 Murtadha Muthahhari, Hak-Hak Wanita dalam Islam, Penerjemah: M. Hashem, (Jakarta: Lentera, 2001), h. 72.
}

pandang etnik tertentu dengan tugas memakmurkan bumi.

Al-Qur'an dengan jelas menyatakan bahwa Allah menciptakan wanita dari sifat dan esensi yang sama dengan pria.

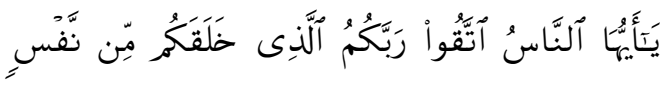

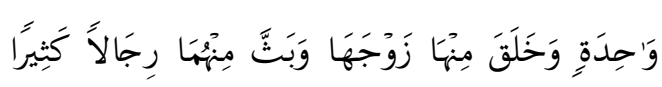

$$
\begin{aligned}
& \text { وَنَسَاءََ ..... }
\end{aligned}
$$

"Hai sekalian manusia, bertakwalah kepada Tuhan-mu yang telah menciptakan kamu dari seorang diri, dan dari padanya Allah menciptakan isterinya, dan dari pada keduanya Allah memperkembang biakkan laki-laki dan perempuan yang banyak...” (Q.S. An-Nisa': I)

Bahkan, pria dan wanita dapat bersaing secara sehat untuk mencapai kualitas taqwa di hadapan Allah, sebagaimana dalam ayat berikut:

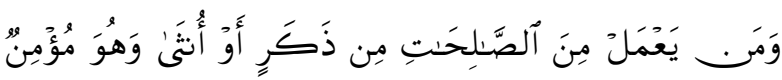

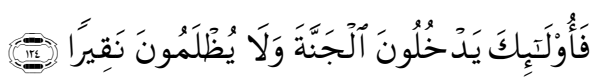

"Barangsiapa yang mengerjakan amal-amal saleh, baik laki-laki maupun wanita sedang ia orang yang beriman, Maka mereka itu masuk ke dalam surga dan mereka tidak dianiaya walau sedikitpun.” (Q.S. An-Nisa': 124)

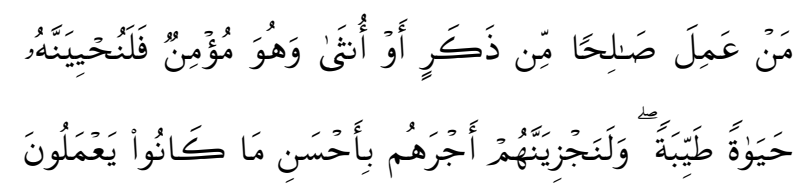

"Barang siapa yang mengerjakan amal saleh, baik lakilaki maupun perempuan dalam keadaan beriman, Maka Sesungguhnya akan Kami berikan kepadanya kehidupan yang baik dan Sesungguhnya akan Kami beri Balasan kepada mereka dengan pahala yang lebih baik dari apa yang telah mereka kerjakan.” (Q.S. an-Nahl: 97)

Dari situ dapat diambil kesimpulan, bahwa yang dijadikan pegangan dalam pandangan Islam adalah wanita dan pria, atas dasar kenyataan bahwa yang satu adalah wanita dan yang satu adalah pria, tidaklah identik dalam segala hal. Dunia mereka tidak persis sama, dan watak serta pembawaan mereka tidak dimaksudkan supaya identik. Oleh sebab itu, maka dalam banyak hal, kewajiban, hukuman, keduanya tidak harus menempati kedudukan yang sama.

Gambaran Umum Wanita dalam Sejarah Islam 
Pada pembahasan sebelumnya, telah dijelaskan bagaimana keadaan kaum wanita pada masa Jahiliyyah. Keberadaan mereka tidak diakui, kelahirannya merupakan aib bagi keluarga, dan hanya menimbulkan masalah. Jangankan untuk menjadi seorang pemimpin, lahir dalam keadaan hidup saja sudah merupakan suatu keberuntungan, karena begitu sebuah keluarga melahirkan anak perempuan, maka seketika itu juga keluarga tersebut akan mengubur bayi perempuan itu hidup-hidup. Namun semenjak Islam datang, meski tidak sepenuhnya, derajat wanita terangkat, mereka mulai mendapatkan hak-haknya, terutama hak untuk hidup.

Pada masa awal Islam, wanita telah memainkan peran yang sangat penting, terutama keikutsertaan mereka dalam mendukung dan membantu perjuangan Rasulullah. Mereka terdiri dari keluarga-keluarga, sahabat-sahabaat Rasulullah. Di masa awal-awal Islam, mereka berperan sebagai pendukung dakwah dan risalah Rasulullah, seperti peran yang dimainkan oleh Khadijah. Pada masa selanjutnya, peran mereka lebih luas lagi, seperti pengajar dan penyampai ilmu, terutama tentang alQur'an dan hadis-hadis Rasulullah, seperti peran 'Aisyah binti Abu Bakr.

Peran wanita yang sangat strategis pada masa itu adalah keikutsertaan mereka di medan pertempuran bersama Rasulullah. Pahlawan perempuan yang paling populer adalah Nusaibah binti Ka'ab (Ummu Umarah) yang berjuang dengan busur panah dan pedang untuk melindungi Rasulullah pada perang Uhud dan mendapat luka-luka yang serius.

$\mathrm{Hal}$ tersebut menjadi bukti bahwa, pada masa awal Islam, wanita mempunyai hak, peran, dan kewajiban yang sama dan setara dengan pria, terutama dalam hal yang berkaitan dengan urusan di luar rumah. Islam mewajibkan kepada setiap muslim dan muslimat untuk belajar dan mencari ilmu. Seperti yang dilakukan oleh isteri-isteri Rasulullah, beliau-beliau mempunyai kewajiban untuk mempelajari dan mengajarkan alQur'an. 'Aisyah Ummu al-Mukminin sangat terkenal karena pengetahuannya yang luas mengenai hadis, figh, sejarah, syair, pengobatan, dan ilmu astronomi, dan bahkan telah ikut serta dalam persoalan-persoalan politik dan memimpin kaum muslimin dalam perang Jamal. $^{5}$

Peranan wanita pada era Umayah, dapat dilihat pada diri Umi Khalid isteri Yazid, Ummu Banin yang merupakan permaisuri Khalifah al-Walid bin Abd Malik, yang menjadi sangat terkenal karena pengetahuan dan wawasannya yang luas dan visinya

5 Siti Musdah Mulia, Menuju Kemandirian Politik Perempuan, (Yogyakarta: Kibar Press, 2008), h. 56. yang jauh ke depan. Keduanya sering menjadi tempat meminta saran dan pendapat oleh khalifah yang berkuasa.

Pada masa Abbasyiyah juga dapat dilihat dari Ummu Salamah isteri dari Abu al-Abbas, begitu juga Zubaydah yang sangat berperan dalam politik suaminya yaitu Harun ar-Rasyid. Kedua wanita ini sangat besar pengaruhnya pada keputusan-keputusan politik khalifah. ${ }^{6}$

Di India, pada tahun $1236 \mathrm{M}$, terdapat seorang Sultanah (sultan perempuan) terkenal bernaman Sultanah Radhiyah, keturunan Turki yang mempunyai kekuasaan atas Delhi, Sultanah Syajarat alDur yang juga keturunan Turki penguasa Mesir yang meraih kekuasaan di Kairo pada $1250 \mathrm{M}$, dia memerintah dengan baik. Ratu bangsa Barber yang mendapat gelar Malikah (raja perempuan) adalah Zainab an-Nafzawiyah yang berbagi kekuasaan dengan suaminya, Yusuf bin Tasyfin, penguasa sebuah imperium besar Afrika Utara hingga Spanyol antara 106I-II07 M. ${ }^{7}$

Beberapa contoh di atas telah memberi gambaran yang terang bagaimana bangsa wanita telah memainkan peran strategis di ranah percaturan politik dalam perjalanan sejarah Islam. Aktivitas wanita sangat dihormati dan peran mereka pun sangat strategis, baik secara langsung maupun hanya melalui orang-orang yang berpengaruh di sekelilingnya, suami atau puteranya sebagai penguasa.

\section{Gambaran Umum wanita sejak Kolonial hingga Pasca Kemerdekaan Indonesia}

Kedudukan wanita di Indonesia dari waktu ke waktu menunjukkan adanya perubahan, sejarah mencatat hampir di seluruh daerah di Indonesia pernah mengalami pengaruh besar dari penguasa wanita dalam pemerintahan. sebagai contoh kepemimpinan seorang wanita di Indonesia yaitu, Ratu Sima dari Kerajaan Keling, Tri Bhuwanatunggadewi dari Wangsa Isyana, Suhita dari Majapahit yang terkenal dalam cerita Menakjingga dan ratu Kalinyamat dalam sejarah Demak, menunjukkan bahwa dalam masyarakat tradisional Indonesia tidak menolak penguasa perempuan.

Kemunduran status wanita dalam masyarakat disebabkan beberapa hal. Feodalisme yang berkembang di zaman Mataram menempatkan posisi isteri sebagai lambang status sang pria, menggeser posisi wanita dari kedudukan subjek menjadi objek. Kedatangan Islam yang diboncengi budaya Arab menganggap wanita lebih

\footnotetext{
${ }^{6}$ Ahmad Syafi'I Mufid, Dialog Agama dan Kebangsaan, (Jakarta: Zikrul Hakim, 2001), h. 218

${ }^{7}$ Siti Musdah Mulia, Menuju Kemandirian Politik..., h. 62.
} 
rendah dari pria. Demikian juga beberapa kebiasaan dalam adat, seperti perkawinan usia dini, kawin paksa, penolakan atau perceraian sepihak yang tidak menguntungkan wanita. Poligami terjadi di setiap lapisan masyarakat, terutama di kalangan orang berada, dan muncul anggapan bahwa suami yang memiliki isteri lebih dari satu menunjukkan kekayaan dan kemampuan seseorang untuk mengurus lebih dari satu rumah tangga. ${ }^{8}$

Berbeda dengan tokoh wanita sebelumnya, R.A Kartini yang juga dilahirkan dan dibesarkan di daerah yang sama dan dari kalangan "ningrat" merasakan betapa kaum wanita diberlakukan tidak adil. Wanita desa adalah aktifis ekonomi di samping sebagai ibu rumah tangga, pendidikan bagi kalangan wanita pada saat itu masih sangat langka, kecuali bagi sebagian priyayi atau bangsawan.

R.A. kartini oleh wanita Indonesia dianggap sebagai pelopor kemajuan wanita meskipun tidak banyak perbuatan nyata yang dia lakukan selama masa hidupnya yang relative singkat (2I April 1879-17 September 1904), tetapi cita-citanya yang dimuat dalam kumpulan surat-suratnya "Habis Gelap Terbitlah Terang" memiliki pengaruh yang besar dalam menggerakkan wanita Indonesia. Banyak hal yang dikemukakan dalam bukunya tersebut seputar persoalan yang terjadi di tengah masyarakat Indonesia yang perlu diperbaiki, di antaranya yaitu kawin paksa, poligami, perceraian sepihak oleh suami, dan pingitan. Beliau menikah dengan R.M A.A. Djodjodhiningrat (bupati Rembang), dan meninggal setahun kemudian, beberapa hari setelah melahirkan putra pertamanya. ${ }^{9}$

Pergerakan perempuan pada zaman Jepang tidak dapat berkembang dengan leluasa karena segala sesuatunya diatur oleh pemerintah Jepang. Di semua tempat didirikan perkumpulan untuk wanita dengan nama Fudjinkai yang telah ditentukan arah dan programnya, diantaranya yaitu mengunjungi tentara yang sakit, pemberantasan buta huruf, mengurus dapur umum, bekerja dengan sukarela, menanam dan membersihkan taman. Perkumpulan inipun tidak dapat bergerak leluasa karena selalu diawasi oleh Jepang.

Kondisi wanita di Indonesia mulai mengalami perkembangan dengan kehadiran Kartini dan munculnya organisasi-organisasi yang mendorong partisipasi perempuan dalam seluruh aspek kehidupan. Di Jawa Barat dikenal Raden Dewi Sartika sebagai pelopor kemajuan wanita, yang pada tahun 1904 mendirikan sekolah gadis pertama, hingga pada tahun 1912 sudah Sembilan sekolah gadis didirikan di

\footnotetext{
${ }^{8}$ Hamka Hasan, Tafsir Gender: Studi Perbandingan antara Tokoh Indonesia dan Mesir, (Jakarta: Badan Litbang dan Diklat Departemen Agama RI, 2009), h. 35.

${ }^{9}$ Ahmad Syafi'i Mufid, Dialog Agama dan..., h. 219.
}

berbagai kabupaten, 50\% berada di Pasundan. Pada tahun yang sama, di Jakarta didirikan perkumpulan Putri Mahardika yang bertujuan memajukan pengajaran anak-anak perempuan dengan bantuan Budi Utomo.

Pada tahun-tahun berikutnya, dibentuklah perkumpulan-perkumpulan bagi wanita dan badanbadan lain untuk mendirikan sekolah-sekolah Kartini. Semua ini bertujuan untuk memperbaiki pendidikan dan meningkatkan ketrampilan kaum wanita. ${ }^{10}$

Sejak Indonesia merdeka, wanita segera ikut berjuang untuk mempertahankan kemerdekaan, banyak dari mereka yang ikut berjuang di medan peperangan, membantu Palang Merah Indonesia, mengurus dapur umum, dan lain-lain. Bahkan pada masa ini, sejumlah perkumpulan mengadakan Kongres Wanita Indonesia hingga II kali untuk merumuskan arah perjuangan wanita Indonesia dalam rangka mewujudkan kesejahteraannya.

Selama berlangsungnya kongres itu, banyak hal didiskusikan, diantaranya yaitu RUU Perkawinan (1950) yang berkeadilan termasuk poligami, perdagangan perempuan dan anak-anak (1902), pelacuran (1902), partisipasi wanita dalam pendidikan, hukum, ekonomi, social, dan politik.

Gambaran umum partisipasi wanita dalam jabatan public seperti parlemen, diantaranya badan parlemen sementara sebelum MPRS (26 wanita dari 413 anggotanya), DPR 1955 (19 wanita dari 27I anggotanya). Di samping itu, posisi kabinet juga ada Ny. Maria Ulfah SH dan Ny. Dra. S.K. Trimurti, Ny Rusiah Sarjono SH (Menteri Sosial Perempuan 1962-1966), Ny. Artati Marzuki (Menteri Pendidikan dan Kebudayaan 1964-1966). Demikian juga di bidang diplomasi, sejumlah wanita duduk sebagai duta besar di Negara Eropa dan Asia serta PBB. Perkembangan wanita pasca kemerdekaan memperlihatkan peningkatan yang signifikan, hal itu disebabkan oleh kesadaran wanita itu sendiri dan juga Negara mulai mengakomodasi mereka dalam jabatan-jabatan publik."

\section{Kepemimpinan Wanita dalam Hukum Islam}

I. Pemimpin dalam Perspektif Islam

Dalam pandangan Islam, pada prinsipnya semua orang dapat dan berpeluang menjadi pemimpin. Dalam makna sederhana, bahwa Allah SWT menciptakan manusia di muka bumi ini sebagai khalifah (pemimpin), makna pemimpin itu pun tidak harus memiliki spectrum yang luas, pemimpin dapat juga dilihat dalam keluarga dan seterusnya.

\footnotetext{
${ }^{10}$ Hamka Hasan, Tafsir Gender ..., h. 41.

${ }^{11}$ Hamka Hasan, Tafsir Gender..., h. 43.
} 
Pemimpin yang difahami dalam Islam adalah pemimpin yang esensi kepemimpinannya bersifat integrative, karena itu berkembang suatu paradigma bahwa suatu kepemimpinan dalam Islam harus bersifat ideologis. Artinya, kepemimpinan itu didasarkan pada ketentuan yang bersifat definitive oleh kesatuan pandangan mengenai agama, kehidupan sosial, kehidupan politik kenegaraan, ekonomi, hukum, dan budaya. Itulah sebabnya bahwa pemimpin agama juga merupakan pemimpin bagi rakyat dan bangsa.

Pemimpin yang benar adalah pemimpin yang tingkah lakunya tidak menyimpang dari poros kebenaran yang diwahyukan oleh agama, pemimpin yang menjunjung tinggi moralitas, yang senantiasa berbuat adil, pemimpin yang menyejukkan dan membahagiakan mereka yang dipimpin.

Pemimpin Islam yang sejati terletak pada kesepadanan antara perkataan dan perbuatan, bersifat mulia, rendah diri, tidak sombong, jauh dari kehidupan yang berlebihan, bersikap jujur, adil dan meletakkan sandaran kepemimpinannya kepada wahyu Allah dan sunnah Rasul serta akal sehat. Dengan demikian, seorang pemimpin akan berorientasi pada perbaikan kehidupan rakyatnya dengan memberikan manfaat kepada rakyatnya. ${ }^{12}$

2. Pemimpin dalam Perspektif Sosiologi

Dalam perspektif sosiologi, pemimpin atau elite pemimpin pada prinsipnya merupakan fenomena yang lahir dari konstruksi social budaya yang dapat membedakan antara satu individu dengan individu lainnya, atau satu komunitas dengan komunitas lainnya. Elit pemimpin dalam perspektif sosiologi dapat diartikan sebagai anggota masyarakat yang paling berbakat.

Seorang sosiolog, Mills, berpendapat bahwa alite adalah mereka yang menduduki posisi atas dalam institusi ekonomi, militer dan politik, membentuk kurang lebih elit kekuasaan yang terintegrasi dan terpadu yang keputusan-keputusan pentingnya menentukan struktur dasar dan arah masyarakat.

Dalam setiap komunitas, kehadiran seorang pemimpin merupakan sebuah kebutuhan, karena setiap warga masyarakat membutuhkan seorang pemimpin yang menjadi panutan atau contoh bagi mereka dalam proses penciptaan ketentuan dan pola interaksi dalam komunitasnya. Dengan adanya pemimpin, suatu masyarakat atau komunitas akan dapat mempertahankan kehidupan sosial, politik, agama, ekonomi, dan budaya. Kepemimpinan sebagai alat untuk menghindari ekspansi pihak-pihak luar dalam komunitas itu. ${ }^{13}$

3. Kepemimpinan Wanita dalam Perspektif Fiqh Klasik

Pemimpin dalam suatu organisasi maupun negara sangat diperlukan. Peran pemimpin bukan hanya menjadi tonggak berjalannya kegiatan, namun juga menjadi pemersatu anggota maupun warga negara yang dinaunginya. Bercermin pada budaya dan norma yang ada di Indonesia, pemimpin adalah jabatan seorang laki-laki. Laki-laki sudah menjadi simbol kepemimpinan sejak dulu, dan wanita selalu identik dengan kelemahan, tidak berfikir logis, dan mengandalkan naluri. $\mathrm{Hal}$ inilah yang menyebabkan wanita jarang ditempatkan dalam posisi penting. Ketimpangan yang dinamakan sebagai kodrat wanita ini bahkan menjadi sebuah konstruksi sosial.

Kepemimpinan wanita dalam figh klasik memang masih menjadi perdebatan di kalangan ulama', baik itu kepemimpinan secara umum maupun kepemimpinan dalam artian lain, seperti memposisikan wanita dalam jabatanjabatan penting, menjadi hakim misalnya. Sebagian dari mereka ada yang menyetujui dan sebagian lagi menolak hal tersebut.

Dalam ilmu figh, salah satu syarat menjadi seorang pemimpin adalah harus dari kaum laki-laki, sehingga menjadikan wanita sebagai hakim juga tidak diperbolehkan, kecuali pengikut 
Abu Hanifah. Sebagaimana dijelaskan Jalam sabda Rasulullah SAW “، كَنْ يُفْلِح قَوُْمْ وَلَّوَا أَمَرَهُمُ امَرَأَة pengambilan keputusan oleh seorang hakim membutuhkan kesempurnaan pendapat, akal, kecerdasan, dan pengalaman dalam masalah-masalah kehidupan. sedangkan seorang wanita itu memiliki kekurangan dalam berfikir, memiliki pandangan yang sempit, dikarenakan sedikitnya pengalaman dan pandangan mereka terhadap realita kehidupan yang ada. Disamping itu, seorang hakim harus banyak berkomunikasi dengan laki-laki dari kalangan ulama', saksi-saksi, dan para pihak yang bersengketa. Sementara seorang wanita dilarang untuk berinteraksi dengan laki-laki sebagai bentuk menjauhi fitnah, dan Allah SWT juga telah memperingatkan tentang sifat pelupa dari kaum wanita dalam alBaqarah: 282

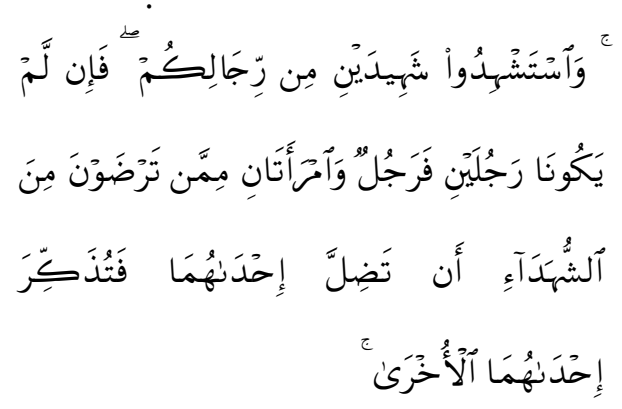

“dan persaksikanlah dengan dua orang saksi dari orang-orang lelaki (di antaramu). jika tak ada dua orang lelaki, Maka (boleh) seorang lelaki dan dua orang perempuan dari saksi-saksi yang kamu ridhai, supaya jika seorang lupa Maka yang seorang mengingatkannya." (Q.S. al-Baqarah: 282)

Selanjutnya, seorang wanita juga tidak layak mendapatkan jabatan yang penting, tidak boleh diberikan kekuasaan atas sebuah Negara, oleh karena itu Rasulullah dan para sahabat belum pernah memberikan jabatan kepada seorang wanita, baik itu sebagai seorang hakim, maupun sebagai penguasa daerah atau Negara.

Adapun pendapat Hanafiyah, seorang wanita diperbolehkan menjadi hakim dalam masalah harta benda atau hukum perdata, karena mereka diperbolehkan memberikan kesaksian dalam bidang muamalat. Dan orang yang menjadikannya sebagai seorang hakim dianggap berdosa sebagaimana yang

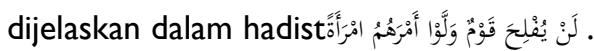
Adapun dalam masalah-masalah hudud dan qishas atau dalam hukum pidana, maka wanita tidak diperbolehkan menjadi hakim. Karena dia tidak mempunyai hak memberikan kesaksian dalam masalah jinayah. Sebagaimana yang diketahui, bahwa seseorang yang memiliki keahlian untuk menghukumi juga harus memiliki keahlian dalam memberi saksi.

Sedangkan pendapat Ibnu Jarir at-Thabari, seorang wanita boleh menjadi hakim secara mutlak, sebagaimana kebolehan menjadikan seorang wanita sebagai mufti, maka diapun boleh menjadi seorang hakim. ${ }^{14}$

Lebih lanjut, perdebatan tentang kebolehan seorang wanita menjadi pemimpin di kalangan ulama ini terbagi menjadi dua kelompok, ${ }^{15}$ yaitu:

a. Kelompok yang tidak memperbolehkan, mereka mengajukan beberapa dalil, diantaranya yaitu:

I) Surat an-Nisa' ayat 34, yang secara umum difahami bahwa rijal menjadi pemimpin atas wanita bukan hanya dalam lingkup keluarga tetapi meliputi lingkungan yang lebih luas seperti Negara, sebagaimana yang diungkapkan oleh alMaududi, karena kepemimpinan merupakan sifat laki-laki. Selanjutnya adalah surat alBaqarah ayat 228 , yang menurut al-Ashafani ayat ini merupakan penjelasan bahwa kedudukan laki-laki itu di atas kaum wanita, baik dalam hal kemampuan intelektual maupun dalam bidang politik.

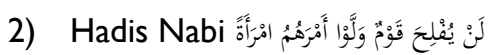

3) Hadis tentang kekurangan perempuan, yaitu perempuan

\footnotetext{
14 Wahbah Zuhayli, Fiqh al-Islam wa 'Adillatuh, juz 6, (Damaskus: Fiqh al'Am, 1984), h. 483.

15 Naqiyah Mukhtar, Kontroversi Presiden Perempuan, (Purwokerto: STAIN Purwokerto Press, 2009), h. 35.
} 
kurang menggunakan aktivitas akalnya, bukan kurang kemampuannya, dalam situasi tertentu misalnya karena sibuk dengan kehamilan, melahirkan, kemudian juga kukurangan tugas-tugas keagamaan seperti ketika menstruasi.

4) Diqiyaskan dengan ketidak bolehan wanita menjadi imam shalat bagi laki-laki

5) Wanita tidak pantas menghadiri kelompok laki-laki, bahkan suaranya merupakan fitnah. Dan tugas utama seorang wanita adalah berhubungan dengan masalah reproduksi yang membutuhkan tenaga, fikiran serta waktu yang luar biasa, yang tidak memungkinkan seorang wanita untuk memikirkan hal lain, terlebih lagi untuk menjadi seorang pemimpin.

b. Kelompok yang menerima

Pada umumnya, kelompok yang menerima kepemimpinan wanita ini menyatakan bahwa alQur'an menjunjung tinggi martabat wanita, tidak sedikit ayat yang menyetarakan antara pria dan wanita. Selain itu, ukuran seseorang ditentukan oleh kualitas taqwanya, bukan dari jenis kelaminnya. Oleh karena itu, tidak ada larangan terhadap seorang wanita untuk berperan aktif dalam aktivitas politik, termasuk menjadi pemimpin suatu Negara sekalipun.

Tugas amar ma'ruf nahi munkar yang terdapat dalam surat atTaubah ayat 7I difahami sebagai tugas bersama antara pria dan wanita, keduanya sejajar dan samasama dapat berperan dalam mengelola urusan-urusan masyarakat. Bahkan menurut Mahmud, setiap pria dan wanita hendaknya mengikuti perkembangan masyarakat suapaya dapat mengetahui dan memberi saran dalam berbagai bidang kehidupan. ${ }^{16}$

${ }^{16}$ Naqiyah Mukhtar, Kontroversi Presiden Perempuan..., h. 50.
Kesimpulannya, di antara beberapa alasan ataupun faktor yang menyebabkan munculnya pendapatpendapat dalam fiqh klasik tentang larangan wanita menjadi seorang pemimpin adalah:

a. Pengaruh keadaan sosial budaya di Arab ketika Islam turun, di mana mereka menganut system monarkhi dan selalu laki-laki yang menjadi sulthan (raja).

Sebelum Rasulullah SAW diutus menjadi rasul di tengah-tengah masyarakat Arab, Bangsa Arab adalah bangsa yang akrab dengan sebutan masyarakat jahiliyyah, yaitu masyarakat yang mengalami penyimpangan-penyimpangan, baik akidah, moralitas, hukum maupun agama. Dengan demikian, secara umum karakteristik kehidupan masyarakat Arab pra Islam ketika itu dapat digambarkan sebagai berikut: tradisi kesukuan (kabilah) yang sangat kental, system social politik yang sangat eksklusif, factor keturunan dianggap leboh penting dari pada kemampuan, mempertahan system hierarki social yang kuat, merendahkan harkat dan martabat wanita. ${ }^{17}$

b. Dalam sejarah Islam, semua Nabi dan Rasul adalah seorang laki-laki

c. Begitu juga di Indonesia, dengan system kerajaan pada zaman dahulu, yang menjadi raja adalah seorang laki-laki dan jabatan itu bersifat turun temurun kepada anak laki-lakinya.

d. Imam shalat tidak pernah dari seorang wanita, tetapi seorang lakilaki, syarat ini tercantum dalam kitab fiqh klasik maupun modern. Dan para ulama sepakat bahwa wanita tidak dibenarkan menjadi pemimpin shalat bagi kaum laki-laki.

e. Dalam al-Qur'an, kaum laki-laki adalah pemimpin bagi kaum wanita,

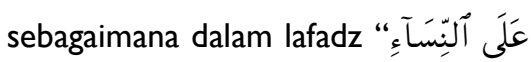

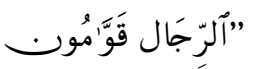

17 Roibin, Penetapan Hukum Islam dalam Lintas Sejarah, (Malang: UIN Maliki Press, 2010), h. 22. 


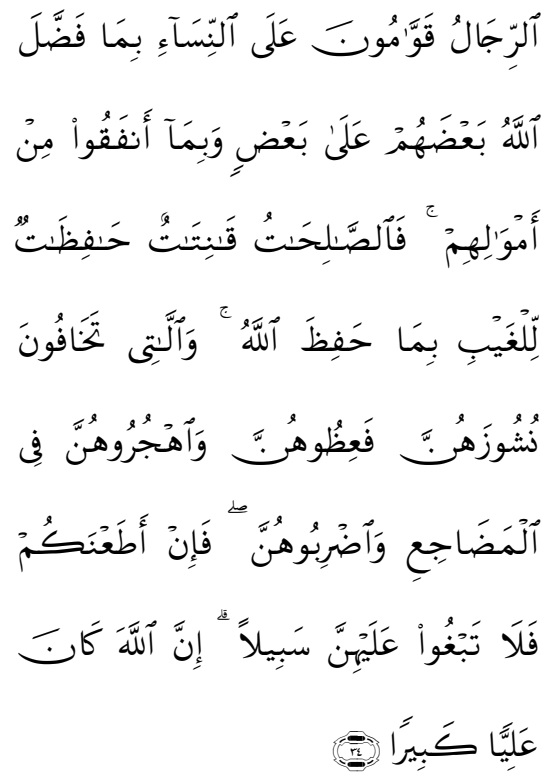

"kaum laki-laki itu adalah pemimpin bagi kaum wanita, oleh karena Allah telah melebihkan sebahagian mereka (laki-laki) atas sebahagian yang lain (wanita), dan karena mereka (lakilaki) telah menafkahkan sebagian dari harta mereka. sebab itu maka wanita yang saleh, ialah yang taat kepada Allah lagi memelihara diri ketika suaminya tidak ada, oleh karena Allah telah memelihara (mereka), wanita-wanita yang kamu khawatirkan nusyuznya, maka nasehatilah mereka dan pisahkanlah mereka di tempat tidur mereka, dan pukullah mereka. kemudian jika mereka mentaatimu, Maka janganlah kamu mencari-cari jalan untuk menyusahkannya. Sesungguhnya Allah Maha Tinggi lagi Maha besar." (Q.S. an-Nisa': 34)

Ayat tersebut menjadi titik awal perdebatan kepemimpinan wanita di ranah publik. At-Tabari dalam tafsirnya menjelaskan "ar-rijalu qawwamuna 'ala an-nisa' " bahwa kepemimpinan pria atas wanita didasarkan atas refleksi kekuatan fisik, pendidikan, dan kewajibannya untuk memenuhi seluruh kewajiban yang ditentukan oleh Allah. Keutamaan laki-laki ditinjau dari segi kekuatan akalnya serta kekuatan fisiknya, sehingga kenabianpun menjadi hak bagi kaum laki-laki. Dengan kekuatan akal dan fisik inilah, kepemimpinan dalam bentuk khalifah seperti imam sholat, kewajiban jihad, adzan, saksi, perwalian nikah, talak, rujuk, dan batasan jumlah isteri semuanya disandarkan kepada lakilaki.

f. Adanya hadist nabi yang berbunyi:

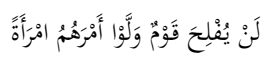

"tidak akan bahagia suatu kaum, apabila mereka menyerahkan kepemimpinannya kepada wanita"

g. Wanita memang lemah, baik dari segi fisik, akal, maupun agama

h. Wanita tidak dapat menikahkan dirinya, tetapi harus dengan wali

\section{Pengaruh Sosiologi dalam Fiqh Kepemimpinan Wanita}

Figh merupakan karya intelektual tentang hukum dengan basis teks-teks keagamaan, terutama alQur'an dan hadits. Rumusan pemikiran ini diperlukan untuk memberikan jawaban terhadap persoalanpersoalan manusia dalam berbagai hal. Figh selalu dihasilkan melalui aktivitas pikiran atau intelektual yang tidak berada dalam kehampaan ruang dan waktu dengan berbagai problematika dan logikanya sendiri. Dalam arti lain, figh sebagai karya intelektual sesungguhnya senantiasa bergumul dengan fakta-fakta historis dan sosiologis.

Fakta-fakta historis-sosiologis ini menyimpan makna-makna dan substansi-substansinya sendiri. Oleh karena itu, figh yang lahir dalam sejarah tertentu tidak dapat ditarik ke ruang dan waktu yang lain, yang secara substantif telah berbeda. Hal ini juga berarti bahwa, untuk menghukumi persoalan-persoalan yang dihadapi pada masa sekarang tidak selalu dapat diberlakukan hukum yang telah berlaku pada masa lampau. Kerancuan atau kekeliruan akan terjadi apabila memaksakan berlakunya fiqh untuk seluruh ruang dan waktu yang telah berbeda atau berubah secara substansial. ${ }^{18}$

Dalam konteks apapun, tarikh atau sejarah atau histori dianggap sebagai entitas yang sangat mendasar dalam kehidupan. Sejarah adalah gambaran riil dari potret kehidupan yang sangat varian dan dinamis. Akumulasi perilaku social keagamaan maupun perilaku social lainnya dalam kehidupan masyarakat plural dapat diamati dan dikritisi melalui fakta empiric peninggalan sejarah kehidupan manusia. Dengan demikian, semua perilaku social, baik perilaku positif

\footnotetext{
${ }^{18}$ Husein Muhammad, Fiqh Perempuan, (Yogyakarta: LKiS, 2001), h. 184.
} 
maupun negative akan dapat dilacak melalui data-data historis.

Atas dasar ini, fungsi maupun kontribusi sejarah bagi generasi setelahnya adalah memberikan pelajaran mendasar bagi kehidupannya yang tentu dianggap mampu memberikan inspirasi bagi praktik kehidupan yang akan datang. Pada akhirnya, sejarah tidak dapat dilepaskan dari kehidupan manusia, sejarah akan selalu menjadi inspirasi kehidupan mereka, dan kehidupan mereka pada gilirannya juga akan menjadi sejarah baru bagi generasi yang akan datang, selalu dan akan terus demikian. Inilah potret sebuah kehidupan yang selalu terdaur ulang, perputaran yang tiada henti. Sejarah mewarnai realitas dan realitas mewarnai sejarah, sebuah proses idalektik yang dinamis. ${ }^{19}$

Apabila dihubungkan dengan surtat an-Nisa' ayat 34 , maka kita harus memahami ayat ini sebagai bersifat sosiologis dan kontekstual. Posisi wanita yang ditempatkan sebagai subordinat laki-laki sesungguhnya muncul dan lahir dari sebuah bangunan masyarakat yang peradabannya dikuasai oleh laki-laki, atau yang disebut dengan masyarakat patriarki. Pada masyarakat semacam ini, wanita tidak diberikan kesempatan mengaktualisasi dirinya dan berperan dalam posisiposisi yang menentukan.

Meskipun ayat al-Qur'an menyebutkan demikian, akan tetapi penyebutan atau pencantuman perempuan dalam al-Qur'an sudah merupakan kemajuan yang luar biasa apabila dibandingkan dengan bagaimana orang-orang Arab jahiliyyah memperlakukan mereka. Dapat dipahami bahwa langkah al-Qur'an yang demikian itu merupakan langkah yang strategis dalam mengangkat derajat wanita, dan hal itu hanya bisa dilakukan secara berangsur-angsur.

Oleh karena itu, akan menjadi kesalahan besar apabila kita selalu ingin memposisikan wanita dalam setting budaya yang seperti itu ke dalam setting sosial dan budaya modern seperti sekarang ini. sedangkan, seperti yang kita ketahui, bahwa syariat Islam itu diatur demi mencapai kemaslahatan dan keadilan umatnya. Dan kemaslahatan serta keadilan itu dapat terwujud apabila kita mampu memposisikan sesuatu secara proporsional dan kontekstual.

Dewasa ini, pandangan tentang kelebihan kaum laki-laki dan kelemahan kaum wanita dari sisi intelektual dan profesi tengah digugat. Kehebatan intelektual dan profesi merupakan salah satu syarat kepemimpinan, dengan syarat tersebut terbuka kemungkinan yang luas bagi kaum wanita untuk menduduki posisi-posisi publik, termasuk menjadi presiden.

\footnotetext{
${ }^{19}$ Roibin, Penetapan Hukum Islam ..., h. 3.
}

Hal ini dapat dilihat melalui fakta-fakta yang ada di masyarakat. Fakta-fakta tersebut dapat dilihat secara langsung dalam realitas sosial dan sejarah modern yang membuktikan bahwa telah banyak wanita yang dapat melakukan tugas-tugas yang selama ini dianggap hanya dapat dilakukan dan sekaligus dimonopoli oleh laki-laki. Kita telah menyaksikan sejumlah perempuan yang menjadi kepala Negara, kepala pemerintahan, gubernur, ketua parlemen, dan ketua partai politik.

Realitas ini tentu saja memperlihatkan bahwa pandangan yang meyakini kealamiahan dan kodratiah sifat-sifat wanita tidaklah benar. Yang benar adalah semua itu merupakan produk bangunan sosial yang sengaja diciptakan, dan pada sisi lain, kenyataan itu juga memperlihatkan adanya sebuah proses kebudayaan yang semakin maju.

Latar belakang penolakan kepemimpinan wanita di atas sebenarnya tidak bersumber dari latar belakang keagamaan, melainkan kebudayaan, baru kemudian mereka mencari pembenaran melalui agama. Bahkan, dalam kasus seorang pemimpin wanita tersandung masalah misalnya, mereka beramai-ramai menyatakan bahwa penyebabnya adalah gender. Hal ini menjadi bukti bahwa budaya adalah faktor lain dari sebab banyaknya penolakan terhadap kepemimpinan wanita, terutama pada masyarakat tradisional.

\section{Pandangan masyumi}

Program perjuangan Masyumi menyebutkan "dengan mengakui bahwa perbedaan sifat dan pembawaan antara kaum wanita dan pria juga membawa perbedaan tugas dan lapangan pekerjaan bagi mereka masing-masing, maka Masyumi berpendapat bahwa hak-hak politik, social, dan ekonomi kaum wanita adalah setaraf dengan pria”. Secara teoritis, draf Undang-Undang Dasar Republik (Islam) yang dirumuskan oleh Masyumi, memungkinkan seorang wanita untuk menjadi Presiden serta Perdana Menteri dan jabatan-jabatan public lainnya. ${ }^{20}$

\section{Pandangan Musdah Mulia}

Sebagai bagian dari warga Negara, wanita Indonesia secara normative dalam konstitusi dijamin mempunyai akses berpartisipasi dalam kekuasaan dan pengambilan keputusan. Oleh sebab itu, wanita juga perlu berpartisipasi dalam lembaga-lembaga politik, seperti eksekutif, yudikatif, dan legislative.

Kaum wanita perlu menempati posisi dalam lembaga-lembaga politik untuk terlibat dalam proses pengambilan keputusan, sebab tanpa melibatkan

\footnotetext{
${ }^{20}$ Yusril Ihza Mahendra, Modernisme dan Fundamentalisme dalam Politik Islam, (Jakarta: Penerbit Paramadina, 1999), h. 270.
} 
aspirasi kaum wanita dalam berbagai kebijakan publik akan melahirkan kebijakan publik yang tidak pro terhadap kaum wanita atau peraturan yang diskriminatif terhadap kaum wanita.

Kehadiran kaum wanita dalam struktur kekuasaan dan proses pengambilan keputusan publik diharapkan akan memberi kontribusi pemikiran dalam menentukan agenda politik dan program pembangunan. $^{21}$

\section{Penutup}

Wanita mempunyai kedudukan yang tinggi dan istimewa dalam Islam, dalam pandangan Islam, kedudukan wanita di keluarga memberikan makna penjagaan syariat, dialah pendidik dan penanam utama syariat sejak dini kepada anggota keluarganya. Islam juga tidak pernah menganut pengutamaan dan diskriminasi yang menguntungkan pria dan merugikan wanita, sebagai buktinya, tidak ada satu ayat pun dalam al-Qur'an yang menyebutkan bahwa wanita diciptakan dari bahan yang lebih hina dari pada pria.

Gambaran umum wanita, baik dalam sejarah Islam maupun sejarah Indonesia, pada awalnya mereka merupakan pihak yang tersubordinasi oleh kaum pria, keberadaannya tidak diakui, aktivitasnya dibatasi, dan tidak mempunyai peran dalam kehidupan selain dalam masalah reproduksi. Namun sebenarnya, mulai awal Islam datang, wanita sudah melakukan banyak peran, baik dalam hal peperangan maupun penyebaran ilmu pengetahuan, meski tidak semuanya tercantum dalam buku-buku sejarah Islam. Begitu juga di Indonesia, berawal dari cita-cita R.A Kartini, wanita-wanita Indonesia mulai bangkit, dan seiring berjalannya waktu, banyak dari mereka yang menjadi pemimpin dalam berbagai organisasi kemasyarakatan, politik, bahkan presiden.

Ulama fiqh berbeda pendapat mengenai kepemimpinan wanita, ada yang memperbolehkan dan ada yang menolaknya. Kelompok yang menolak kepemimpinan wanita berargumen bahwa kepemimpinan itu merupakan hak kaum pria sebagaimana dalam surat an-Nisa' ayat 34, dan masih banyak lagi alasannya. Sementara kelompok yang memperbolehkan kepemimpinan wanita berlandaskan pada kesamaan derajat pria dan wanita dalam alQur'an, serta perintah amar ma'ruf nahi munkar yang sama-sama diemban oleh pria maupun wanita sebagai khalifah di bumi ini, sehingga tidak menutup kemungkinan bagi wanita untuk menjadi pemimpin.
Adanya larangan tentang kepemimpinan wanita sebenarnya bukan lahir dari faktor keagamaan, melainkan dari kondisi social budaya maupun social historis dalam masyarakat itu sendiri. Apabila dalam masyarakat zaman dahulu wanita tidak dapat menjadi pemimpin karena dianggap lemah dari berbagai segi, intelektual dan kemampuan misalnya. Hal itu tidak dapat diterapkan lagi dalam kondisi social masyarakat saat ini, di mana kaum wanita sudah banyak yang mengenyam pendidikan setinggi-tingginya, dalam suatu kasus bahkan kecerdasan mereka telah melebihi kaum pria, hal ini tentunya membuka kesempatan yang luas bagi kaum wanita untuk menjadi pemimpin.

\section{Daftar Pustaka}

Hartati. 2006. Ibu Teladan di Era Global: dalam Perspetif Islam. Jakarta: Pusat Studi Wanita UIN Syarif Hidayatullah.

Hasan, Hamka. 2009. Tafsir Gender: Studi Perbandingan antara Tokoh Indonesia dan Mesir. Jakarta: Badan Litbang dan Diklat Departemen Agama RI.

Jurdi, Syarifuddin. 20I0. Sosiologi Islam dan Masyarakat Modern. Jakarta: Kencana.

Mahendra, Yusril Ihza. 1999. Modernisme dan Fundamentalisme dalam Politik Islam. Jakarta: Penerbit Paramadina.

Mufid, Ahmad Syafi'i. 200I. Dialog Agama dan Kebangsaan. Jakarta: Zikrul Hakim.

Muhammad, Husein. 200I. Fiqh Perempuan. Yogyakarta: LKiS.

Mukhtar, Naqiyah. 2009. Kontroversi Presiden Perempuan. Purwokerto: STAIN Purwokerto Press.

Mulia, Siti Musdah. 2008. Menuju Kemandirian Politik Perempuan. Yogyakarta: Kibar Press.

Muthahhari, Murtadha. 200I. Hak-Hak Wanita dalam Islam. Penerjemah: M. Hashem. Jakarta: Lentera.

Roibin. 2010. Penetapan Hukum Islam dalam Lintas Sejarah. Malang: UIN Maliki Press.

Thalib, Muhamad. 1999. Solusi Islam terhadap Dilema Wanita Karir. Yogyakarta: Wihdah Press.

Zuhayli, Wahbah. 1984. Figh al-Islam wa 'Adillatuh. juz 6. Damaskus: Fiqh al'Am.

Syaikhu, Syaikhu, Ariyadi Ariyadi, and Norwili Norwili. "Fikih Muamalah: Memahami Konsep dan Dialektika Kontemporer." (2020).

${ }^{21}$ Siti Musdah Mulia, Menuju Kemandirian Politik ..., h. 86. 